\title{
MOdERNIDADE, POLITICA E PRÁXIS NEGRA NO pensamento de Clóvis Moura
}

Fábio Nogueira de Oliveira*

Resumo O pensamento de Clóvis Moura (1925-2003) contribuiu, de forma crítica, à reconstrução simbólica do negro como sujeito político em torno da práxis negra e da defesa de uma sociologia do negro, antiacadêmica (construída fora da sociologia produzida pelas instituições universitárias e em oposição a ela) e militante. Em seus escritos dos anos 1970 e 1980, como fenômeno sociopolítico, a práxis negra se inscreve como parte da modernidade e da conflituosa integração do negro na sociedade ocidental e como categoria-chave na tradução do marxismo a partir da perspectiva do negro.

Palavras-chave Clóvis Moura; modernidade; sociologia; práxis negra; intelectuais negros.

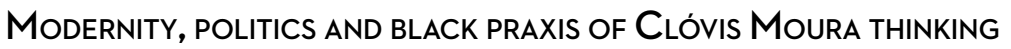

Abstract The thought of Clovis Moura (1925-2003) contributed, in a critical way, to the symbolic reconstruction of the black as a political subject around the black praxis and defense of a black sociology, anti-academic (built outside and in opposition to sociology produced by universities) and activist. In his writings of the 7os and 8os, such as socio-political phenomenon, the black praxis is written as part of modernity and conflictual integration of black in Western society and can be seen as the key category in the translation of Marxism from the black perspective.

Keywords Clovis Moura; modernity; sociology; black praxis; black intellectuals.

* Graduado em Ciências Sociais pela USP, mestre em Sociologia e Direito pela UFF. Atualmente, é doutorando em Sociologia pela USP e professor assistente do Instituto Multidisciplinar de Saúde da UFBA. 


\section{INTRODUÇÃO}

Nascido em Amarante, no Piauí, em 1925, Clóvis Moura tem uma vasta e contínua produção bibliográfica sobre o negro - que é anterior à publicação de Rebeliões da senzala, seu livro de estreia em 1959, e que percorreu praticamente toda a sua vida (seu último livro, Dicionário da escravidão negra no Brasil, foi publicado post-mortem, em 2004). Uma característica estruturante da obra de Moura - foram mais de vinte livros, além de artigos e capítulos de livros - é sua ênfase no processo de resistência violenta do negro ao escravismo.

Apesar do reconhecido caráter pioneiro de Rebeliões da senzala (GomEs, 1995; Gomes; ReIs, 1996) em destacar o caráter ativo do negro na luta em seu processo de emancipação - e, com isso, ampliar as possibilidades de análise histórica e sociológica da resistência negra sob o escravismo -, a escassa literatura sobre Clóvis Moura não se debruça sobre seu pensamento, suas categorias de análise e sua apropriação do marxismo ${ }^{1}$. Este artigo tem como objetivo contribuir para compreender o pensamento de Clóvis Moura considerando a práxis negra como categoria-chave e relacionando-a, na modernidade, com o processo de reconstrução simbólica do negro como sujeito político.

Defende-se, aqui, também, que a categoria de práxis negra no pensamento mouriano é uma tradução do marxismo, a partir da perspectiva do negro e que, por sua vez, fundamenta uma sociologia do negro, antiacadêmica (construída fora e em oposição à sociologia produzida pelas instituições universitárias) e militante².

\section{UTOPIAS, MODERNISIMO E MODERNIDADE NEGRA}

Em OAtlântico negro, Paul Gilroy busca compreender como a experiência dos negros na diáspora - corporificada a partir da escravidão, do deslocamento e do exílio - está amalgamada à formação da modernidade (GILroy, 2001). Define, assim, o Atlântico Negro como um mesmo mutável: as experiências diaspóricas negras

1 Com exceção dos trabalhos de Maestri (2004), Konrad (2007, p. 115-133) e Mesquita (2002).

2 Em seu livro A sociologia posta em questão (1978), Clóvis Moura traça um balanço crítico das ciências sociais sob o impacto das ditaduras militares instaladas na América Latina e, em especial, no Brasil, em 1964 (tendo recrudescido, em 1968, com o AI-5). Em linhas gerais, o livro de Clóvis se estrutura a partir da oposição entre sociologia acadêmica e sociologia da práxis: a primeira representaria uma forma de "ciência aplicada na medida em que coonesta o atual tipo de sociedade [a capitalista], racionalizando-o (no sentido weberiano)" e a segunda, uma "anti-sociologia capaz de produzir ruptura, superando o dogmatismo acadêmico e apresentando, na sua proposta, novas normas de ação" (MourA, 1978, p. 10; 20). Dessa maneira, a sociologia antiacadêmica de Clóvis Moura tem relação direta com o conceito de práxis e se situa nos marcos de uma sociologia militante. 
são formações transculturais e internacionais das quais emergem diferentes formas de construir identidades culturais, raciais e políticas em relação à modernidade e na modernidade, a qual foi, originalmente, uma forma de pensar o Ocidente.

Antônio Sérgio Guimarães entende a modernidade como uma ruptura com a ideia de tradicional e clássico, predominante na representação do Ocidente como civilização e que tem como raízes o cultivo da herança greco-romana, que data da Renascença, bem como a expansão dos domínios da Europa nórdica e ocidental (Guimarães, 2003).

Na Europa, a partir do final do século XIX, o movimento da vanguarda artística avançou pela conjunção das transformações dos costumes e do modo de vida característico da belle époque, desencadeado pelo desenvolvimento tecnológico e científico e pela crise da economia capitalista que precipitaria a Primeira Guerra Mundial (1914-1918).

Essas experiências artísticas, que se caracterizam por expressar a realidade de forma diferenciada e múltipla, estão representadas por movimentos como: o cubismo, em que se trabalhou a qualidade dos planos geométricos superpostos e cuja maior expressão foram as telas do pintor espanhol Pablo Picasso (1881-1973); o dadaísmo, que libertou a expressão artística da lógica, coerência e coesão, protagonizado pelo poeta e ensaísta romeno Tristan Tzara (1896-1963); o futurismo, liderado pelo italiano Marinetti (1876-1944) e que exalta a velocidade, a máquina e o movimento; e o surrealismo do escritor francês André Breton (1896-1966).

A transformação no gosto e na estética do mundo ocidental, sobretudo como reação à tragédia e à carnificina da Primeira Guerra, materializada no sentimento dessas vanguardas, incorpora as expressões estéticas do negro e suas manifestações culturais contíguas como modernas (GuIMARÃEs, 2003).

Essa ruptura em torno da percepção do desenvolvimento do mundo ocidental, fundamentada na crítica aos pressupostos comportamentais, estéticos e culturais sedimentados durante séculos de inculcação e controle social (EliAs, 1993 apud GUIMARÃEs, 2003) oferece abrigo às representações que os negros passam a fazer de si mesmos e forma um repertório de constructos intelectuais, artísticos e políticos modernos.

Portanto, para Antônio Sérgio Guimarães (2003, [s/p]), a modernidade negra emerge como um processo de

inclusão cultural e simbólica dos negros à sociedade ocidental, mas sob a palavra negra se escondem personas muito diversas: o escravo e o liberto das plantações; o africano, o crioulo, o mestiço e o mulato das sociedades coloniais americanas; 
o norte-americano, o latino-americano, o africano e o europeu do mundo ocidental pós-guerra.

A modernidade negra pode ser dividida em dois momentos (não necessariamente coincidentes): o primeiro, caracterizado por representações positivas dos negros, elaboradas por intelectuais ligados às vanguardas literárias e artísticas europeias (cubismo, negrismo e modernismo); o segundo, em que os negros, em consonância com esse movimento, passam a representar positivamente a si mesmos (GuIMARÃEs, 2003). No entanto, as respostas intelectuais à inclusão dos negros ao Ocidente não se apresentaram de forma uniforme e linear: elas variaram de acordo com o momento histórico e as tendências culturais dominantes; logo, a construção de identidades raciais dependeu de seus diferentes contextos discursivos.

Mônica Grin (2002, p.201) por exemplo, compara a modernidade brasileira, surgida nos anos 1930, que reifica a mestiçagem e a ambivalência racial como marcas de nossa nacionalidade, com o purismo racialista presente nos contextos históricos norte-americano e europeu. Dessa maneira, diferentes formas de integração dos povos e nações ao Ocidente se refletem em distintas formas de manifestação da modernidade negra e das identidades raciais: se, na formação dos estados nacionais europeus e norte-americano, prevaleceram a pureza identitária, no Brasil, a identidade nacional se constituiu como hibridismo e mestiçagem racial e cultural, em torno de uma identidade homogênea.

A modernidade negra, em termos da distribuição das populações negras na diáspora africana, pode ser organizada em três formas originárias: a norte-americana e do Caribe anglófono, a dos países latino-americanos de colonização portuguesa e espanhola e a dos países do Caribe francófano.

A vertente anglo-americana se caracteriza pela afirmação de uma cultura negra relacionada à cultura dominante, mas independente desta. Já nos países colonizados por espanhóis e portugueses, os negros afirmam sua identidade em bases mestiças.

Nos países do Caribe francófano, como um híbrido entre as duas formas anteriores, constroem-se culturas nacionais e afirmam-se subculturas negras (Guimarães, 2003). Essas modernidades negras, do ponto de vista histórico, refletem diferenciadas respostas à elevação de milhões de negros escravizados à condição de cidadãos da sociedade burguesa. Em termos cronológicos, as ondas de emancipação se iniciam com a Revolução Haitiana (1804) e se encerram com a abolição completa da escravização no Brasil, em 1888 (GuIMARÃEs, 2003). 
Essas modernidades, por sua vez, representam distintas formas de apropriação da modernidade e contradiscursos sobre a integração dos negros na diáspora, no Ocidente expandido (Gilroy, 2001).

No entanto, é necessário considerar as diferentes estratégias de integração e superação de barreiras - sociais e raciais - erigidas contra os negros nas sociedades pós-abolição e como elas assumirão um caráter coletivo (Sptizer, 2001, p. 206). No plano político, o contexto de luta cada vez mais radicalizado dos negros na diáspora contra o racismo (luta em defesa dos direitos civis, Black Panthers), o recrudescimento do Apartheid, na África do Sul, e a formação de novos estados nacionais africanos, nos anos 1950 e 1960, contribuíram para o estremecimento das fronteiras que restringiam o acesso à cidadania e circunscrevia à Europa, à América e aos Estados Unidos os conceitos de soberania, igualdade e autonomia política.

Naturalmente, a partir de suas distintas posições e de seus interesses no mundo ocidental, os intelectuais negros se movimentam: inventam-se tradições (Hobsbawm; RANGer, 1997) e fundam-se novas cosmologias de pertencimento nacional, "racial" e regional que ligam grupos sociais subalternizados e disseminam novas percepções acerca da participação política destes no mundo moderno (SPTIZER, 2001, p. 206).

Por exemplo, se compreendemos que um processo similar ocorre em relação às "populações indígenas” (povos originários) na América Latina, podemos fazer uma comparação entre duas construções culturais relevantes, no sentido de demonstrar o imbricamento entre alternativas discursivas à integração política das populações afro-descendentes e originárias ao Ocidente: o “comunismo incaico” de José Carlos Mariátegui (1894-1930) e a "República de Palmares" de Clóvis Moura.

O crítico literário, jornalista e sociólogo peruano José Carlos Mariátegui nasceu em Monquecua, em 1894, e faleceu em Lima, em 1930, com apenas trinta e seis anos de idade. Começou a escrever poemas para a imprensa limenha, sob o pseudônimo de Juan Croniqueur, dedicou-se à crítica literária e se aproximou das correntes nacionalistas que agitaram a república peruana no início do século XX. No prólogo ao romance do escritor Valcarcél, Tempestad en los Andes, Mariátegui (1975, p. 21) expressa da seguinte maneira sua crença no ressurgimento da cultura indígena peruana:

A fé no ressurgimento indígena não provém de um processo de "ocidentalização" material da terra quechua. Não é a civilização, não é o alfabeto do branco, o que enobrece a alma do índio. É o mito, é a idéia da revolução socialista. A espe- 
rança indígena é totalmente revolucionária. O mito, a idéia, em si mesmos, são agentes decisivos no despertar de outros velhos povos, de outras velhas raças em colapso: hindus, chineses etc. A história universal tende, hoje mais do que nunca, a reger-se pelo mesmo quadrante. Porque há de ser o povo incaico, que construiu o mais desenvolvido e harmônico sistema comunista, o único insensível à emoção mundial? (grifo nosso).

Já para Clóvis Moura, a República Palmarina era um misto de monarquia e democracia e tinha como objetivo a valorização dessa construção política negra vista e representada como moderna (em comparação, naquele momento, com o estatuto colonial-escravista).

De acordo com Érica Mesquita (2002, p. 58):

Para [Clóvis] Moura, Palmares era uma síntese entre república e simultaneamente monarquia. República, pois cada quilombo que integrava Palmares tinha seu representante, e este decidia, de forma autônoma, ou seja, conjuntamente com o seu povo como solucionar problemas incidentes em seu reduto; monarquia, pois possuíam um rei com toda distinção hierárquica-social, muitas vezes não só social como também religiosa, e que em tempos de guerra exercia poderes absolutos. Era dessa forma um modelo singular de governar o povo (grifo nosso).

Portanto, essas tradições e cosmologias devem ser vistas como construções simbólicas sobre modos de vida apresentados ao mundo ocidental como modernos e que, no contexto de luta política dos negros africanos e na diáspora, radicalizado entre as décadas de 50 e 80 do século XX, incorporam-se às teorias marxistas, terceiro-mundistas e nacionalistas revolucionárias e formam uma teia multiforme de projetos, versões e representações sobre sociedades futuras (utopias) e "comunidades imaginadas" (ANDERSON, 2005).

A tradução do marxismo a partir da perspectiva do negro, no pensamento mouriano, tem como categoria-chave a noção de práxis. É a práxis - considerada como ação de rebeldia e resistência violenta ao escravismo - que confere ao negro um caráter e, por sua vez, torna-o sujeito.

Nas próximas seções, analisa-se, durante os anos 1970 e 1980, como Clóvis Moura contribui, de forma crítica, à reconstrução simbólica do negro como sujeito político em torno do praxismo negro e da defesa de uma sociologia do negro, antiacadêmica e militante. 


\section{A NEGRITUDE COMO PRÁXIS E A PRÁXIS DA NEGRITUDE}

O movimento da negritude francófona surgiu em Paris, nos anos 1930, com o encontro dos intelectuais negros Leopold Senghor (1906-2001), Aimé Césaire (19132008) e Leon Damas (1912-1978), que fundaram a revista Etudiant Noir (1934).

Em linhas gerais, a negritude é um movimento de recusa da assimilação cultural do branco e de valorização da experiência cultural africana (MunANGA, 1988). Em janeiro de 1974, em Dakar, capital do Senegal, representou a bancada brasileira, junto com o antropólogo pernambucano Renê Ribeiro (1914-1990), no Colóquio Sobre Negritude e América Latina, sob a presidência de Leopold Senghor (1906-2001). Durante o encontro, que teve como objetivo principal aproximar os intelectuais latino-americanos da temática da negritude, Clóvis teve contato, entre outros, com os intelectuais negros Nicomedes Santa Cruz (1925-1992), do Peru, e Zapata Olivella (1920-2004), da Colômbia.

As impressões de Clóvis sobre o conclave foram sintetizadas no artigo "Negritude: uma solução, nunca um problema”, publicado no Jornal de Debates, em 1974 (reeditado em 1983, em Raízes do protesto negro) (MourA, 1983).

A primeira parte do artigo de Clóvis Moura se atém à polêmica presente durante o Colóquio entre os que definiam a negritude como conceito - atitude dos negros diante do mundo dos brancos (posição representada por German de Granda, da Espanha, e Renê Ribeiro, do Brasil) e os que defendiam a negritude como posição "existencial dinâmica” (com a qual se alinhava, entre outros, Clóvis Moura e Nicomedes Santa Cruz).

Estabeleceu-se, portanto, uma oposição entre os "acadêmicos" que definiam a negritude como um conceito e/ou um campo estudo, de um lado; e, de outro, os "militantes" - grosso modo, negros - que a interpretavam em termos de ideologia (para ser “vivida e aplicada”) (MourA, 1983, p. 40).

Para Moura, a posição dos cientistas tem como objetivo higienizar a negritude, trabalhá-la etnocentricamente - de fora para dentro - sem, com isso, compreender, em sua "práxis - certa ou equivocada, não importa -, a possibilidade de ser usada como instrumento de conhecimento e ação no processo de transformação da realidade problemática" (MourA, 1983, p. 42).

Para Moura, a negritude, como parte do processo de autoconsciência social, possui densidade científica e relevância, sociológica se pensada em "bases dinâmico-radicais" (Moura, 1983, p. 42). A negritude, diante das barreiras que impediam a assunção dos negros nos espaços brancos, surge como um processo em que o negro se reinventa subjetivamente, em um mecanismo de compensação 
quanto à precária convivência com o mundo branco. Por outro lado, para Clóvis Moura, a negritude extrapola seus limites iniciais - a consciência de si do negro diante do mundo branco - e assume uma significação universal, exteriorizando-se como consciência de uma humanidade alienada.

Nas palavras do sociólogo:

Se a negritude (ou qualquer outro nome que a designe) é a generalização das contradições criadas em uma sociedade opressiva e se ela exterioriza - em termos de conscientização - exatamente o lado mais irracional dessas contradições, então é um instrumento de conhecimento válido a partir daquele conceito de Hans Freyer, segundo o qual só sabe algo sociologicamente quem quer algo socialmente. Isto é: a negritude como método de observação participante representa a unidade entre a teoria e a prática no sentido de desalienar não apenas as populações negras, mas todos aqueles estratos populacionais que, de uma maneira ou de outra, se sentem oprimidos e/ou marginalizados pelo sistema dominante em qualquer parte (MourA, 1983, p. 43).

Foi, no entender de Clóvis Moura, esta posição que prevaleceu durante o Colóquio em Dakar: pensar a relação e as implicações da negritude aplicadas à realidade latino-americana (MourA, 1983, p. 43).

Na segunda parte do artigo, Clóvis faz uma crítica às raízes aristocráticas da negritude, localizando suas origens na atitude de protesto intelectual de negros com formação europeia, radicados na Paris dos anos 1030. No entanto, com a descolonização africana, esse movimento intelectual assumiu caráter político e ideológico (MunANGa, 1988, p. 7).

Com o avanço da descolonização do continente africano, nas palavras de Moura, a negritude passou a ser combatida por setores conservadores e sua ala mais radical (representada por Wole Soyinka). Isso porque a negritude, para Clóvis Moura, correspondeu à conscientização "da opressão que sofriam como negros letrados", mas não somou seu protesto estético “ao protesto social e político passivo e muitas vezes ativo de milhões de negros africanos os quais, sob as condições do colonialismo, sobreviviam na África Negra” (MourA, 1983, p. 44).

No entanto, alguns, a exemplo de Senghor, souberam converter esse protesto estético em práxis política (mesmo que, para Moura, a negritude de Senghor tenha se revelado politicamente equivocada e frustrante) (Moura, 1983, p. 45). A força dos movimentos de libertação africanos e sua integração aos dilemas comuns dos países do chamado Terceiro Mundo deram novo combustível dialético à negritude. 
Por um lado, para Moura, se a negritude, no contexto europeu e africano, sofreu a inflexão da práxis política anticolonialista, no Brasil, por outro lado, isso não ocorreu. A negritude ficou congelada, sem a força dos movimentos políticos de massa, e estagnou como categoria aristocratizante praticada por uma elite negra. Excetuando algumas tentativas isoladas de uma negritude popular e radical refere-se a Solano Trindade -, a negritude brasileira não passou de ideologia de uma elite intelectual negra.

Clóvis Moura faz uma análise crítica da recepção da negritude - como movimento ideológico - por parte dos intelectuais ligados ao Teatro Experimental do Negro (TEN), nos anos 1950 (Moura, 1983, p. 46).

O Teatro Experimental do Negro, em termos históricos, coincide com o intervalo democrático do Pós-Segunda Guerra Mundial (1945-1964) e com o que Antônio Sérgio Guimarães entende por consenso racial-democrático. Com a desmoralização do racismo pseudocientífico, a derrocada do nazismo e dos governos autoritários (fascismo e franquismo), segue a valorização da cultura na interpretação da realidade nacional e, por conseguinte, assiste-se a uma maior afirmação da cultura negra por parte da intelectualidade negra incrustada no Teatro Experimental do Negro (GuimarãEs, 2002, p. 144-149).

Ao contrário de Clóvis Moura (vinculado ao Partido Comunista Brasileiro e, a partir de 1962, ao Partido Comunista do Brasil), Abdias do Nascimento e Guerreiro Ramos, principais expoentes do teatro negro, tiveram suas trajetórias ligadas ao trabalhismo e apoiaram governos que disputavam o legado do varguismo (BARBOSA, 2004; Nascimento, 1980).

Entre os membros do Teatro Popular Brasileiro (Edison Carneiro e Solano Trindade) e do Teatro Popular Brasileiro (Abdias do Nascimento e Guerreiro Ramos), há divergência quanto à linha de atuação do movimento negro: para os primeiros, este deveria abarcar o conjunto das massas negras proletarizadas; para os segundos, deveria se constituir como um movimento cultural de intelectuais negros.

Clóvis Moura defende posição idêntica a de Luiz de Aguiar da Costa Pinto, em Relações raciais no Rio de Janeiro (1998) (Costa Pinto, 1998), que, ao analisar o Teatro Experimental do Negro, defende a coexistência entre organizações da elite negra (no qual se inscreve o teatro negro) e as do negro-massa (escolas de samba, candomblés, etc.).

Para Clóvis Moura, ao fazer da negritude uma "atitude psicológica de revolta inconsciente e vaga de negros intelectuais frustrados no mundo dos brancos" e deixar de emprestar-lhe o caráter de ideologia para ser "vivida e aplicada", esse 
comportamento elitista do Teatro Experimental do Negro levou a um desgaste paulatino (Moura, 1983, p. 47). Por outro lado, essa negritude aristocrática, com a emergência do negro-massa, restringiu-se, naquele momento, a atenuar as tensões e os conflitos entre as áreas brancas enriquecidas e as pobres, majoritariamente negro-parda (Moura, 1983, p. 47).

Durante o pós-Segunda Guerra, entre 1945-1964, Clóvis Moura não participou de organizações antirracistas e do movimento negro, o que se relaciona com o fato de que, ao contrário do que ocorrerá a partir dos anos 1970, nesse período (década de 1940 a 1950), o reconhecimento intelectual de Clóvis Moura não dependia de sua condição "racial”, ou seja, ela não era declarada. As posições político-ideológicas de Moura (comunista) o distanciavam, por exemplo, do TEN - Teatro Experimental do Negro (que possuía suas duas principais lideranças, Abdias do Nascimento e Guerreiro Ramos, ligadas ao trabalhismo).

No longo depoimento ao escritor Luis Silva (Cuti), o militante negro paulista José Correia Leite (1900-1990), fundador da Frente Negra Brasileira (FNB) e da Associação Cultural do Negro (ACN), não fez, entre os anos 1940 e 1960, qualquer referência à participação de Clóvis Moura em algum movimento político negro (ao contrário, por exemplo, de Florestan Fernandes, Sérgio Millet, Solano Trindade e Fernando Góes) (Cuti; Leite, 1992).

As jovens lideranças negras dos anos 1970-1980, oriundas de grupos de esquerda universitária, desencadearam um conjunto de ações no plano político e deram origem, em 1978, ao MNU (Movimento Negro Unificado). Essa liderança, de acordo com Clóvis Moura, seria a ponta de lança do movimento de unidade de todos os setores marginalizados da riqueza nacional (MourA, 1983, p. 43).

Logo, a negritude deixaria de ser um movimento no campo das ideias e ganharia materialidade por meio da política, constituindo-se com o movimento de libertação dos negros e dos oprimidos quanto à exploração econômico-social e à dependência cultural dos antigos centros metropolitanos. Torna-se, dessa forma, força social e política com capacidade de incidir na materialidade do mundo social e definir os rumos do desenvolvimento social.

Destacando o discurso final do ministro da educação, Sr. Alione Sena, no Colóquio, Clóvis Moura acredita que, a partir da reformulação realista da negritude, em especial nas áreas da América Latina e do Terceiro Mundo, esta seria capaz de desempenhar, "como etapa do pensamento, o mesmo papel que os filósofos do século das Luzes, precursores da Revolução de 1789 desempenharam, porque expressa uma vontade de libertação política e de desenvolvimento econômico e cultural” (Moura, 1983, p. 43). 
Trata-se de um movimento ideológico que, a partir de sua realização no mundo, abre espaço para sua própria negação: negritude é consciência histórica, coletiva - forma de encetar a ação política -, com o objetivo de superar uma situação de marginalização objetiva e construir um futuro, um “novo" que é negação do "antigo". No entanto, não o faz sem - ao se colocar na história como um movimento real negar-se a si mesmo como condição desse futuro.

\section{QUILOMBAGEM, HISTÓRIA E PRAXISMO NEGRO}

Em História do negro brasileiro (Moura, 1989), Clóvis Moura utiliza o conceito de quilombagem, movimento no qual o quilombo, como unidade básica do processo de resistência do negro, articulava-se a outras formas de luta, como as insurreições urbanas da Bahia, durante o século XIX, e a revolta dos malês, em 1835, e o bandoleirismo (João Mulungu, em Sergipe, e Lucas da Feira, na Bahia). Dessa maneira, quilombagem é definida como

um movimento de rebeldia permanente organizado e dirigido pelos próprios
escravos que se verificou durante o escravismo brasileiro em todo o território
nacional. Movimento de mudança social provocado, ele foi uma força de desgaste
significativa ao sistema escravista, solapou as suas bases em diversos níveis -
econômico, social e militar - e influiu poderosamente para que este tipo de traba-
lho entrasse em crise e fosse substituído pelo trabalho livre (MouRA, 1989, p. 22).

Como expressão da contradição fundamental da sociedade escravista, que opõe senhores e escravos, a quilombagem não se trata de um movimento de negros organizados em grupos isolados em quilombos, sem inserção nas cidades; ao contrário, é um movimento que, atuando em várias frentes, tem o quilombo - em função de sua quantidade e continuidade histórica - como um núcleo articulador de várias manifestações de resistência negra (cultural, política e religiosa).

Dessa maneira, a variável cultural assume característica de cultura de resistência: o sistema escravista, na luta contra as pressões da quilombagem, inferiorizou a cultura africana, que, por sua vez, passou a desempenhar um papel de autodefesa e proteção social aos negros escravizados e rebeldes. Em outros termos, a cultura negra é apreendida, entremeada ao processo de resistência contra a cultura dominante, forma sua fisionomia no praxismo, na ação ofensiva ou defensiva, em que a cultura não é tomada por "sobrevivência”, mas como práxis reativa ao sistema dominante. 
No ensaio "Sincretismo, assimilação, acomodação, aculturação e luta de classes” (Moura, 1988, p. 34-59), Clóvis Moura faz uma crítica aos conceitos antropológicos com racionalizações dos aparatos colonialistas e neocolonialistas, voltados à dominação das populações “primitivas”. Dessa maneira, opõe-se a uma interpretação culturalista da dinâmica da cultura negra e afro-brasileira - que os conceitos de sincretismo, assimilação, acomodação e aculturação procuram explicar de forma insuficiente, pois partem de uma horizontalidade de posições entre os grupos sociais que trocam e intercambiam traços de suas respectivas culturas e abstraem, dessa maneira, a posição desigual dessas culturas dentro do modo de produção escravista e capitalista.

Nessa perspectiva, Clóvis Moura (1988, p. 46) conclui:

O culturalismo exclui a historicidade do contato, não retratando, por isso, a situação histórico-estrutural em que cada cultura se encontra nesse processo. Desta forma não se pode destacar o conteúdo social do processo e não se consegue visualizar cientificamente quais são aquelas forças que proporcionam a dinâmica social e que, em nosso ver, não têm nada a ver com os mecanismos do contato entre culturas. Para nós este dinamismo não está nesse contato horizontal de traços e complexos de culturas, mas na posição vertical que os membros de cada cultura ocupam na estrutura social, ou seja, no sistema de propriedade.

Isso não significa, no entanto, que os elementos da cultura dominada não tivessem função específica dentro do sistema: eles tenderiam à autodefesa e proteção social do grupo negro-africano, na situação estrutural do escravismo, e evoluiriam para formas de consciência e autonomia política e social. Ao mesmo tempo, a cultura negra é permitida como cultura de folk, suplementar e anexada à cultura dominante, branca e europeia. Por extensão, a cultura negra só será dominante "se houver um processo de mudança social radical que eleve os componentes da cultura afro-brasileira à dominação social e política” (MourA, 1988, p. 48).

Assim, ao considerar a cultura branca e negra como integradas à dinâmica das relações de poder e de produção na sociedade escravista, que opunham brancos e negros como classes antagônicas e, por outro lado, ao atribuir funções específicas a estas, Clóvis Moura politiza a cultura: os sistemas simbólicos e culturais em suas diversas manifestações - religião, culinária, vestimentas, línguas e técnica de trabalho - estão marcados por luta, oposição e contradição.

Outra dimensão que liga quilombagem a praxismo é sua posição quanto ao nível de consciência dos escravos africanos em relação às suas ações. É certo reco- 
nhecer, nesse ponto, que, para Clóvis Moura, malgrado a ação ser o fundamento da práxis negra, a consciência desta é relativa: existiriam formas mais apuradas de luta, de acordo com a capacidade de elaboração política dos negros em luta. Observa-se de antemão, no entanto, que o conceito de quilombagem - formulado por Clóvis Moura - surge paralelamente ao de quilombismo de Abdias do Nascimento (NASCIMENTO, 1980).

A diferença entre ambos é que, para Clóvis Moura, quilombagem é um movimento político-social, dirigido pelos próprios negros contra a sociedade escravista, por representarem uma de suas classes fundamentais (MourA, 1989, p. 22); já o quilombismo, para Abdias, é uma doutrina política dos afro-brasileiros que, nas palavras de Antônio Sérgio Guimarães (2002, p. 100), é "uma das principais matrizes ideológicas que permeavam o movimento negro nos anos 1980, aliando radicalismo cultural a radicalismo político".

Flávio Gomes (1995, p. 14) assevera que, na interpretação mouriana do processo histórico, "as experiências eram quase que exteriores às ações dos sujeitos históricos que as vivenciavam”. Nesse diapasão, Clóvis Moura opõe o negro acomodado - que aceita passivamente a escravidão - ao rebelde, quase-herói, quilombola, antípoda do primeiro e, por outro lado, as formas de resistência passiva (suicídios, fugas, formação de quilombos) e as ativas (revoltas abertas, assassinatos de feitores e ações de guerrilhas dos quilombolas) (Gomes, 1995, p. 15).

A afirmação é correta, no entanto, se, em Rebeliões da senzala (obra de estreia de Clóvis, publicada em 1959), há a preocupação com as formas ativas de resistência - os quilombos, as insurreições e as guerrilhas -, elas assumem outros contornos, sem prescindir de seu núcleo original (o quilombo), ao longo da obra de Clóvis Moura. Dessa maneira, a quilombagem é tomada como práxis, ou seja, processo histórico, de caráter coletivo, decorrente do acúmulo de ações contínuas e permanentes que incidem positivamente na mudança da estrutura social.

Nos marcos desse praxismo negro, seu significado e alcance, situa-se a contribuição mouriana ao pensamento social brasileiro.

Nas condições históricas do escravismo, o nível de apreensão da realidade, mesmo relativo e/ou parcial, que não avançou, para Clóvis Moura, por exemplo, à formação de movimentos massivos ou partidos políticos, ocorre não obstante o fato de a quilombagem influenciar e se articular, como processo, a outras formas de luta de resistência.

Outro ponto importante é que, como veremos, não há para Moura a distinção clássica entre movimentos político e pré-políticos, ou seja, a violência é compreendida como artefato político moderno que conforma o caráter do negro em sua 
experiência na Diáspora (opondo-se, assim, à sua despersonalização e, em termos marxistas, à sua alienação).

Esse caráter aproxima o quilombola do herói romântico ou do político vocacionado ou do soberano. Ao mesmo tempo, Clóvis Moura é um marxista clássico, no sentido de que não se atém ao significado particular de cada ação para os sujeitos nela implicados, mas ao significado geral das ações, consideradas em sua totalidade.

A mediação entre sujeito e estrutura é, assim, a práxis, o que o diferencia de um marxismo enrijecido de base estruturalista - e o faz afirmar a condição de sujeito histórico do negro escravizado -, sem, no entanto, optar por análises micro-históricas.

No ensaio "Reivindicação e consciência no escravismo" (MourA, 1986), Clóvis Moura defende a ideia de que nem todas as lutas entre senhores e escravos tiveram conteúdo insurrecional ou de lutas violentas com base na ocupação, pelos escravos da Fazenda Santana, em Ilhéus, na Bahia, em 1789, estudada pelos historiadores João José Reis e Stuart B. Schwartz. Os escravos enviaram um documento - um tratado de paz - ao seu senhor, no qual reivindicavam, entre outras coisas, redução da jornada de trabalho, controle das ferramentas e terreno para suas hortas, como condição de retornarem ao eito. Em suma, propunham a instauração de um novo regime de trabalho.

Sobre o episódio, Clóvis Moura (1986, p. 76) comenta:

O nível de consciência desses escravos é ininteligível se nos apoiarmos nos conceitos clássicos de escravismo e alienação total do instrumentum vocale de acordo com as teorias tradicionais... Esses cativos estavam dando um salto qualitativo no processo do conhecimento do seu nível de exploração, pois não mais se colocavam como escravos, mas como cidadãos, reivindicando direitos idênticos aos trabalhadores assalariados atuais... Esta ponte estabelecida na consciência destes escravos com a sua situação estrutural é uma demonstração de que, em circunstâncias especiais, os velhos conceitos consagrados sobre as limitações do escravo no processo de conhecimento, muitos deles repetidos por simples mimetismo científico, não são suficientes para interpretarem a realidade emergente (grifos do autor).

Com isso, fala-se de sujeitos - de um nível de consciência em relação às ações imediatas -, por mais que essa consciência não apreenda a totalidade, mas seja, em esfera micro, expressão direta dos dinamismos históricos e estruturais. 
Em seus diversos contornos, a luta e a violência negra, direta e imediata, conformam a quilombagem como práxis negra, seu estatuto político, e influenciaram o sentido das transformações históricas, quando os acontecimentos não foram considerados de forma teleológica.

Assim, o pensamento mouriano se inscreve em um lugar específico dentro da modernidade negra: o de ver na violência negra, e não apenas nas compensações subjetivas de uma identidade afro-centrada, a forma de integração política destes na sociedade ocidental.

\section{PRÁXIS COMO ALTERNATIVA AO EUROCENTRISMO}

Durante os anos 1980 até 2000, Clóvis Moura publicou mais de 20 títulos, entre livros e artigos - quase todos relativos à resistência negra ao escravismo. Rebeliões da senzala, seu livro de estreia, publicado em 1959, receberia mais três edições (1972, 1981 e 1981), e o seu último trabalho, Dicionário da escravidão negra, foi publicado pela Editora da Universidade de São Paulo, em 2004.

Ao mesmo tempo, Clóvis manteve ligação, nos anos 1970, com o movimento negro que se reorganizou no pós-ditadura militar (1964-1989), por meio de entidades como o MNU (Movimento Negro Unificado) e a UNEGRo (União dos Negros pela Igualdade), além de ser colaborador e simpatizante do PCdoB (Partido Comunista do Brasil).

No início de 2000, Clóvis se aproxima do Movimento dos Trabalhadores Rurais Sem Terra (MST) e publica, pela Editora Expressão Popular, o livro Sociologia política da guerra camponesa de Canudos (Moura, 2000). O objetivo do livro é estabelecer a relação entre Canudos e a luta do MST por reforma agrária nos dias atuais.

Sobre Canudos e seu líder, Antônio Conselheiro, Clóvis faz referências às explicações racistas, predominantes em autores como Euclides da Cunha, que relacionam seu caráter messiânico à origem racial de seus membros. Essa explicação racista, para Moura, seria logo desmoralizada e, em sua sequência, as ciências sociais tradicionais, subordinadas aos "estereótipos elitistas e preconceitos de classe, procuraram outros caminhos", tentando apreender a excepcionalidade do movimento de forma "científica" como simples caso de "patologia social" (MourA, 2000, p. 23).

Clóvis Moura critica aqueles que explicam o movimento de Canudos como manifestação “messiânica, pré-lógica, carismática e/ou pré-política”. Dessa maneira, para esses autores criticados por Moura, apenas seriam considerados 
políticos os movimentos que tivessem condições de elaborar um programa de ação e de governo de acordo com os postulados da Revolução Francesa e que desembocassem, como conclusão, em um projeto liberal (MourA, 2000, p. 24). Já os demais movimentos seriam formas rebaixadas e menos apuradas de luta política (banditismo social, milenarismo).

Nesse ponto, Clóvis se volta contra o eurocentrismo do conceito de movimento pré-político. Eric Hobsbawm aplica o conceito de movimento pré-político aos bandidos sociais, a exemplo de Robin Hood, em seu livro Bandidos (Hobsbawm, 1976).

Ao questionar o conceito de movimento pré-político, Clóvis crítica Hobsbawm, nos seguintes termos:

Embora o conceito de movimento pré-político tenha sido cunhado por um historiador grandemente ligado ao pensamento marxista - E. J. Hobsbawm - acreditamos que ele é eurocêntrico, elitista e uma forma neoliberal de analisar e interpretar a dinâmica social. Se o aceitarmos seriam excluídos como políticos todos os movimentos do chamado Terceiro Mundo. A luta de Zapata e Pancho Villa no México, a de Sandino, na Nicarágua, o movimento camponês de Pugachov, na Rússia, todos os movimentos de libertação da África Negra, como o kinbangista, incluindo-se os Mau Mau e o de Lumumba. Todos seriam englobados genericamente sob o título de milenarismo, salvacionismo ou banditismo social e com isto seria descartada a essência dos mesmos, conservando-se apenas a sua casca exterior, a sua forma, sem, no entanto, decifrar-lhe o seu conteúdo político (MOURA, 2000, p. 24).

Segundo Moura, para Marx, os fenômenos e seus respectivos conteúdos não são coincidentes: caso o fossem, não haveria necessidade da ciência. Ainda de acordo com Clóvis, em relação aos movimentos sociais, Marx dizia que "não haverá jamais movimento político que não seja social ao mesmo tempo. Não será senão numa ordem de coisas na qual não haja mais classes, que as evoluções sociais deixarão de ser revoluções políticas” (MARX, 1946, p. 156-157, apud MourA, 2000, p. 24).

Clóvis interpreta livremente essa citação de Marx, ao afirmar que, para o filósofo alemão, não há movimento social que não seja, ao mesmo tempo, político. Dessa maneira, a práxis - a ação - subrepticamente ressurge com o fundamento da consciência, deslocando o sentido original empregado por Marx - que não vê 
movimento político que não tenha fundamento social, mas nem por isso reconhece em todo o movimento social um caráter político.

Dessa forma, Clóvis conclui:

Todos os movimentos que desejam mudança social são movimentos políticos apesar do fato dos seus agentes coletivos não terem total consciência disto. O que vale e determina é o nível de consciência social de cada um e as propostas subseqüentes para a mudança projetada. Mas todos se enquadram (com maior ou menor nível de consciência social) na proposta da transformação revolucionária (ou não) da sociedade (MourA, 2000, p. 25).

Portanto, adequado às condições histórico-sociais de luta dos movimentos nos países do terceiro mundo, o praxismo se torna uma alternativa ao eurocentrismo. No encontro, com o sertão, a utopia sertaneja de Canudos emerge para Clóvis Moura como mais uma prova de que a práxis, a ação coletiva de negros, camponeses e sertanejos, foi uma constante e paciente forma de construir picadas históricas e de se contrapor ao intelectualismo esnobe e artificial que representa os interesses da camarada dirigente estabelecida.

Em suas andanças, Clóvis Moura trouxe ao marxismo o lume negro-rebelde e contribuiu, com o conceito de práxis, à construção de narrativas alternativas à formação da sociedade brasileira, expandindo as possibilidades cognitivas e epistemológicas para o estudo do negro e do racismo pelas ciências humanas.

\section{CONSIDERAÇÕES FINAIS}

O pensamento de Clóvis Moura produziu um contradiscurso alternativo à modernidade eurocêntrica (GILROY, 2001), centrado no sujeito coletivo negro, a partir de sua condição inicial de escravo. Essas construções políticas também operam no plano simbólico e subjetivo e conectam-se a elas, pois são necessariamente fundamentadas em novas percepções acerca da integração e superação da marginalização dos negros como grupo social subalterno na sociedade ocidental.

É dessa maneira que se deve entender a reconstrução simbólica do negro político, do qual a sociologia da práxis é estruturante: a República de Palmares e os quilombos, como "comunidades imaginadas" (ANDERson, 2005), assim como o quilombola, como vanguarda dessa integração violenta na sociedade burguesa, devem ser analisados como uma tentativa de traduzir o marxismo a partir da perspectiva do negro. 
Clóvis Moura não apenas aplicou a interpretação marxista às condições histórico-sociais do negro no escravismo; ele, na acepção de Slajov Zizek, traiu o marxismo (Zizek, 2008, p. 8) ${ }^{3}$, expandiu seu conteúdo original e o enegreceu. A práxis do negro, para Clóvis Moura, enegrece o marxismo e o transfere da realidade pensada pelos intelectuais à realidade vivida pelos sujeitos históricos. É isso o que torna seu pensamento anti-intelectualista.

Assim, dentro do repertório de soluções radicais ao problema do negro, a negritude é reinventada desde o praxismo: a construção subjetiva da identidade negra, como construção política, deve se mover para além das rígidas fronteiras da situação histórica imediata e, a exemplo de outros movimentos intelectuais como o Iluminismo e políticos, como a Revolução Francesa, lançar-se como um novo universal, capaz de ser o catalisador da esperança de realização de um contingente cada vez maior de massas humanas.

Com a práxis radical, o “dilema negro” é superado não apenas subjetivamente, mas de forma objetiva: o significado político da práxis negra é a emancipação humana, a qual, para o autor, ocorreria com a superação da sociedade burguesa. Por outro lado, ao analisar a práxis negra em termos sociológicos, Clóvis Moura propõe libertar a sociologia dos constrangimentos da fragmentação, massificação e impessoalidade do habitus científico.

Como utopia intelectual, na sociologia praxista, sujeito e objeto se constituem na experiência: a expectativa de compreender e transformar o mundo, por meio desse contato, funde-se. Ao mesmo tempo, essa sociologia da práxis legitima um discurso construído fora dos muros da academia.

Também, Rebeliões da senzala (1959), livro de estreia de Clóvis Moura, não parece um caso isolado: segue percurso similar de estudos de outros intelectuais marxistas, também negros ou mestiços ${ }^{4}$. A sociologia da práxis - marxismo - de Clóvis Moura concentrou-se na práxis do negro e, a partir dela, construiu um discurso alternativo sobre o negro político: a quilombagem. A traição do marxismo

3 Para Slavoj Zizek, ao analisar os deslocamentos na história do marxismo, é necessário reconhecer que "Marx precisou da 'traição' de Lênin para levar à prática a primeira revolução marxista: é uma necessidade inerente ao ensinamento 'original' submeter-se e sobreviver a essa 'traição', sobreviver a este ato violento de ser arrancado do seu contexto original e lançado em cenário estranho em que se deve reinventar - só assim nasce a universalidade" (Zizek, 2008, p. 8).

4 Entre eles, destacam-se The black Jacobins [Jacobinos negros] (1934), de C. R. L. James (19011989); How Europe underdeveloped Africa [Como a Europa subdesenvolveu a África] (1972), de Walter Rodney (1942-1989); Peau noire, masques blancs [Pele negra, máscara branca] (1952), de Franz Fanon (1925-1961) e Siete ensayos de interpretación de la realidad peruana [Sete ensaios de intepretação da realidade peruana] (1928), de José Carlos Mariátegui (1984-1930). 
operada por Clóvis Moura e a singularidade do pensamento mouriano chamam para uma reflexão sobre a possibilidade de construção de um "marxismo negro".

\section{REFERÊNCIAS BIBLIOGRÁFICAS}

Anderson, Benedict. Comunidades imaginadas: reflexões sobre a origem e a expansão do nacionalismo. São Paulo: Ed. 70, 2005.

Barbosa, Muryatan. Guerreiro ramos e o personalismo negro. 2004. Dissertação (Mestrado em Sociologia)-FFLCH/USP, São Paulo, 2004.

Costa Pinto, Luís de Aguiar. O negro no Rio de Janeiro. Relações de raças numa sociedade em mudança. Rio de Janeiro: UFRJ, 1998.

Cuti, Luís; Leite, José Corrêa. ...E disse o velho militante José Correia Leite. São Paulo: Secretaria Municipal de Cultura, 1992.

Elias, Norbert. O processo civilizador. Rio de Janeiro: Jorge Zahar, 1993.

Gilroy, Paul. O Atlântico negro. 1. ed. São Paulo: Ed. 34; Rio de Janeiro: Universidade Cândido Mendes, Centro de Estudos Afro-Asiáticos, 2001.

Gomes, Flávio S. História de quilombolas: mocambos e comunidades de senzalas no Rio de Janeiro, século XIX. Rio de Janeiro: Companhia das Letras, 1995.

Gomes, Flávio S.; ReIs, João José (Org.). Liberdade por um fio. História dos quilombos no Brasil. São Paulo: Compahia das Letras, 1996.

Grin, Mônica. Modernidade, identidade e suicídio: o "judeu" Stefan Zweig e o "mulato" Eduardo de Oliveira e Oliveira. Topoi, Revista de Pós-Graduação em História Social da UFRJ, Rio de Janeiro, p. 201-222, jul.-dez. 2002.

GUIMARÃEs, Antônio Sérgio Alfredo. Classes, raça e democracia. 1. ed. São Paulo: 34, 2002. Intelectuais negros e modernidade no Brasil. Working Paper CBS-52-04. Centre for Brazilian Studies: University of Oxford, 2003. Disponível em: <http://www. fflch.usp.br/asag/Intelectuais\%2onegros\%20e\%20modernidade\%20no\%2oBrasil.pdf>. Acesso em: 15 jul. 2010.

Hobsbawm, Eric. Bandidos. Rio de Janeiro: Forense, 1976.

Hobsbawm, Eric; Ranger, T. A invenção das tradições. Rio de Janeiro: Paz e Terra, 1997. KonRAD, Diorge Alceno. Na senzala a resistência, no quilombo a liberdade: a obra de Clóvis

Moura. In: SAntos, Júlio Ricardo Quevedo dos; Dutra, Maria Rita Py (Org.). Nas trilhas da negritude: consciência e afirmação. 1. ed. Porto Alegre: Martins Livreiro, 2007. p. 115-133.

MAESTRI, Mário. Clóvis Moura: uma visão revolucionária precoce sobre o Brasil. In: MAESTRI, Mário. Clóvis Moura: fragmentos de vida e obra. Brasília-DF: Fundação Cultural Palmares/Ministério da Cultura, 2004. CD-ROM. 
MaRIÁtegui, José Carlos. Sete ensaios de interpretação da realidade peruana. São Paulo:

Alfa Omega, 1975.

Mesquita, Érika. Clóvis Moura: uma visão crítica da história social brasileira. 2002.

Dissertação (Mestrado em Sociologia)-IFCH/UnicAmp, Campinas, 2002.

Moura, Clóvis. Rebeliões da senzala. São Paulo: Zumbi, 1959.

. A sociologia posta em questão. São Paulo: Ciências Humanas, 1978.

. Brasil: raízes do protesto negro. São Paulo: Global, 1983.

. Os quilombos e a rebelião negra. 5. ed. São Paulo: Brasiliense, 1986.

. Sociologia do negro brasileiro. São Paulo: Ática, 1988.

. História do negro brasileiro. São Paulo: Ática, 1989.

Sociologia política da guerra camponesa de Canudos. São Paulo: Expressão

Popular, 2000.

Dicionário da escravidão negra no Brasil. São Paulo: EdusP, 2004.

Munanga, Kabengele. Negritude: usos e sentidos. São Paulo: Ática, 1988.

Nascimento, Abdias do. O quilombismo: documentos de uma militância pan-africanista. Petrópolis, RJ: Vozes, 1980.

Sptizer, Leo. Vidas de entremeio. Assimilação e marginalização na Áustria, no Brasil e na África Ocidental (1780-1945). Rio de Janeiro: UERJ, 2001.

Zizek, Slavoj. Mao Tsé-Tung, "Senhor do Desgoverno" marxista. In: Tse-Tung, Mao. Sobre a prática e a contradição. Rio de Janeiro: Jorge Zahar, 2008. 